\title{
Jill Harries, Law and Crime in the Roman World, Cambridge University Press 2007, X+148 stron.
}

W ostatnim czasie znacząco wzrosło zainteresowanie rzymskim prawem karnym w Polsce ${ }^{1}$, choć trend ten wcześniej można zaobserwować w Europie Zachodniej. Badania nad rzymskim prawem karnym prowadził już Th. Mommsen ${ }^{2}$ oraz włoscy romaniści ${ }^{3}$, jednakże to druga połowa XX w. zaowocowała zdecydowanym progresem w tej materii ${ }^{4}$. Warto tu odnotować przede wszystkim pracę, której znaczenia nie sposób przecenić przy analizie rzymskiego prawa karnego ${ }^{5}$. Niestety, żadnej z tych fundamentalnych monografii nie wykorzystała Jill Harries.

Autorka jest międzynarodowym ekspertem w zakresie prawa starożytnego Rzymu ${ }^{6}$. Do tej pory jej badania koncentrowały się nad kodeksem teodozjańskim ${ }^{7}$, ostatnim wiekiem istnienia Imperium Romanum ${ }^{8}$ oraz na prawie i imperium rzymskim w późnym antyku9.

Recenzowana praca nie jest jedyną anglojęzyczną monografią poświęconą szeroko pojętemu rzymskiemu prawu karnemu ${ }^{10}$. Jednakże jest nowatorskim spojrzeniem na tę problematykę, przejawiającym się przede wszystkim na paralelnym prezentowaniu zagadnień prawnokarnych i prywatnoprawnych, tam gdzie było to możliwe, a nie ograniczeniu się tylko do przedstawienia samego prawa karnego.

1 Zob. M. Zabłocka, Romanistyka polska po drugiej wojnie światowej, Warszawa 2002, s. 123-134; eadem, Stan badań polskiej romanistyki, „Studia Prawnoustrojowe” 2007, nr 7, s. 12-13; eadem, Osiagnięcia polskich romanistów w ciagu ostatnich dwóch lat (2006/2007-2007/2008), Zeszyty Prawnicze [UKSW] 8.2, 2008, s. 21-23; M. Kuryłowicz, Rzymskie prawo karne w polskich badaniach romanistycznych, Zeszyty Naukowe Uniwersytetu Rzeszowskiego, Prawo 1.7, 2003, s. 167-176; Por. także K. Amielańczyk, Rzymskie prawo karne $w$ reskryptach cesarza Hadriana, Lublin 2006 (passim).

2 Th. Mommsen, Römisches Strafrecht, Lepizig 1899 (Nachdruck Graz 1955).

${ }_{3}$ C. Ferrini, Diritto penale romano. Teorie generali, Milano 1899; G. F. Falchi, Diritto penale romano, t. I-III, Padova 1932-1937; U. Brasiello, La repressione penale in diritto romano, Napoli 1937.

${ }^{4}$ D. A. Centola, Recenti studi di diritto criminale Romano. Spunti e prospettive di ricerca, SDHI 63, 1997, s. 499-520.

${ }_{5}^{5}$ W. Kunkel, Untersuchungen zur Entwicklung des römischen Kriminalverfahrens in vorsullanischer Zeit, München 1962; (por. liczne jej recenzje: G. Pugliese, BIDR 66, 1963, s. 153-181; G. Crifo, Il processo criminale presilliano, Labeo 10, 1964, s. 90-116; P. A. Brunt, TR 32, 1964, s. 440-449);

${ }_{6}$ Wszystkie dane dotyczące dorobku naukowego prof. Jill Harries zostały zaczerpnięte z poniższych stron internetowych http://www.ihc.ucsb.edu/events/event_files/past/_fall03/harries/index.html z dnia 5 października 2008 r. oraz http://www.st-andrews.ac.uk/classics/people/harries.shtml z dnia 5 października $2008 \mathrm{r}$.

7 The Theodosian Code: Studies in the Imperial Law of Late Antiquity, London 1993.

8 Sidonius Apollinaris and the Fall of Rome, AD 407-485, Oxford 1994.

9 Law and Empire in Late Antiquity, Cambridge 1999.

10 Zob. R.A. Bauman, Crime and punishment in Ancient Rome, London-New York 1996; O. F. Robinson, The Criminal Law of Ancient Rome, London 1996. 
Przedmiotowa monografia składa się z dziewięciu rozdziałów. Już we wstępie autorka zaznacza, że jej praca nie ma charakteru przewodnika po prawie karnym, a badania skoncentrowane są na trzech aspektach: jak Rzymianie definiowali przestępstwa i jak sobie z nimi radzili z punktu widzenia społecznego i prawnego, jaką rolę odgrywały strony oraz sądowe rozstrzygnięcia w okresie cesarstwa. Autorka sugeruje, że czasami te czynniki determinowały zmianę rozstrzygnięć (bardziej niż sam cesarz rezydujący w Rzymie), ale gdy analizuje się te działania z perspektywy współczesnej, to nie zawsze przynosiły one lepszy rezultat w porównaniu do poprzedzających je rozwiązań. Ostatnim aspektem badań jest ukazanie postrzegania przestępstwa przede wszystkim przez innych autorów niż rzymscy juryści. Trzech jest tu najbardziej reprezentatywnych: Kwintylian, M.T. Cycero oraz A. Gellius (s. IX).

Praca dzieli się de facto na dwie części. Początkowo J. Harries koncentruje się na aspekcie rzymskiego procesu karnego (rozdz. 1-3, częściowo tej problematyki dotyka także ostatni rozdział), by kolejne rozdziały (4-11) poświęcić analizie poszczególnych przestępstw (crimina).

W pierwszym rozdziale (Competing discourses, s. 1-11) zostały przedstawione kwestie wprowadzające w dalszy tok wywodów. J. Harries ukazuje rzymską próbę definiowania przestępstwa i podkreśla wpływ społeczności na jej rozwój, akcentując fakt uznawania przez Rzymian pewnych czynów niezgodnych z punktu widzenia moralnego (np. nefas, delictum, maleficium etc.). Autorka słusznie podkreśla, że te terminy wprowadzają pewną niekonsekwencję w ich pojmowaniu i jako namacalny przykład podaje dwojakie rozumienie maleficum już przez samego Gaiusa (zob.: G. II, 81 oraz G. I, 128) (s. 5). J. Harries zauważa, że ewolucja sądownictwa w okresie cesarstwa była wynikiem obserwacji dotychczasowej tradycji prawniczej i nowości, które dzięki elastyczności praktyki sądowej umożliwiły (raczej niż władza cesarza czy praeses provinciae) działanie, zgodnie z ich oczekiwaniem (s. 7). Konkludując, autorka stwierdza, że w starożytnym Rzymie było kilka warstw zainteresowanych szerokim pojmowaniem przestępstwa: juryści interpretujący przestępstwo przez pryzmat prawa cywilnego, a następne karnego, sędziowie (jednoosobowo lub kolegialnie), adwokaci, których rola sprowadzała się bardziej do przekonywania niż prezentowania swojego stanowiska, same strony szukające w procesie zadośćuczynienia bądź odwetu i wreszcie ustawodawca okresu cesarstwa, postrzegający siebie jako czołowego „mściciela zła” ('avenger' of evil) (s. 11).

Kolejny rozdział (Public process and the legal tradition, s. 12-27) wprowadza czytelnika w skomplikowaną materię rzymskiego procesu karnego. Rozważania rozpoczynają się od prezentacji iudicium populi, opisują przebieg procesu przed zgromadzeniem ludowym (trzykrotne zwołanie contio przez oskarżycieli, którymi byli trybunowie plebejscy, edylowie kurulni oraz plebejscy, czy wreszcie kwestorzy, po którym następowało właściwe orzeczenie w sprawie ewentualnie zakwestionowanie go $\mathrm{w}$ drodze provocatio ad populum). Autorka trafnie zauważa, że czyny uznawane za przestępne naruszały dobro publiczne i były odzwierciedleniem społecznej woli ich penalizowania. Stąd też J. Harries wymienia takie przestępstwa jak perduellio, parricidium, stuprum (s. 14-15). Celnym spostrzeżeniem dokonanym przez autorkę jest wskazanie, że sądownictwo na zgroma- 
dzeniu ludowym dało późniejszą legitymację stronom, sądowi oraz sędziom - choć poddanym pewnym ograniczeniom - na wykształcenie się szerokiej władzy dyskrecjonalnej, pozwalającej uznać, co było przestępstwem „publicznym” czy kryminalnym (s. 16).

Kontynuując prezentację rzymskiego procesu karnego, J. Harries omawia powstanie trybunałów karnych (quaestiones). Słusznie zaznacza, że pierwsze quaestiones były powoływane ad hoc (np. na mocy SC de Bacchanalibus przeciwko uczestnikom kultu Bakchanaliów w II w. p.n.e.), by dopiero po 149 r. p.n.e., czyli od lex Calpurnia de repetundis, pojawiły się stałe trybunały karne (quaestiones perpetuae) (s. 17). Apogeum tego rodzaju sądownictwa przynoszą czasy Sulli. Warto odnotować trafne wyartykułowanie przyczyny stopniowej erozji quaestiones perpetuae na rzecz rozwijającej się cognitio, którą było kontrolowanie kreacji i modyfikacji nowych przestępstw przez samą elitę w senacie (uwzględniając wskazówki cesarza). Odzwierciedleniem tej praktyki jest np. SC Messalianum penalizujące bezprawne zachowanie adwokatów oraz SC Caludianum. Ponadto lex Cornelia de sicariis et veneficis została rozszerzona za panowania Tyberiusza w 27 albo 29 r. n.e. i doprowadziła do karania krzywoprzysięzców i tych, którzy przyjęli łapówkę w celu złożenia fałszywych zeznań (s. 24). Inny czynnik erozji z systemu prawnego quaestiones na rzecz cognitio J. Harries upatruje w wykształceniu się karania sprawców zgodnie z ich statusem społecznym (honestiores-humiliores).

Analizując kwestie rzymskiego procesu karnego, autorce umknęła praca W. Kunkla ${ }^{11}$, której nie sposób nie zacytować, omawiając tę problematykę. Ponadto niewątpliwym mankamentem jest rezygnacja z krótkiego podsumowania rozważań poczynionych w tym rozdziale, choć praktycznie każdy (wyjątkiem jest tu też rozdz. 7) J. Harries kończy krótką konkluzją.

Słusznym założeniem wydaje się przedstawienie w odrębnym rozdziale (Cognitio, s. 28-42) spostrzeżeń dotyczących cognitio extra ordinem ${ }^{12}$. J. Harries zauważyła, że przez elastyczność tej formy procesu prawo rozwinęło się zgodnie z oczekiwaniem procesujących się stron (s. 32). Rozważając cognitio extra ordinem, autorka nie mogła pominąć kwestii tortur (tormenta). Powołując się na źródła prawnicze stwierdza, że stosowanie tortur nie musiało być pierwszym środkiem dowodowym, jakiemu poddany był oskarżony. Przytacza także zdanie Ulpiana (D. 48,19,8,3) stwierdzające, że tormenta powinny być tak stosowane, aby nie prowadziły do śmierci torturowanego. Zauważa jednak, że ogólna reguła, mówiąca o poddaniu wszystkich torturom w procesie o maiestas, uległa stopniowemu rozszerzeniu w praktyce. Jako przykład podała fałszowanie pieniędzy, używanie togi purpurowej, które to czyny zbliżyły się do szeroko pojętego w okresie cesarstwa crimen maiestatis (s. 34). Interesujące jest przytoczone dwojakie stanowisko Kwintyliana w przedmiocie tortur. Raz wskazał on, że torturowany mógł być „twardy” i przekonywać,

${ }^{11}$ Patrz. przyp. 5 oraz tego samego autora szczegółowe hasło quaestio [w:] RE, t. 23.1, szp. 739 i n. [= Kleine Schriften zum römischen Strafverfahren und zur römischen Verfassungsgeschichte, Weimar 1974].

${ }^{12}$ Wydaje się, że zasadne byłoby odesłanie zainteresowanego czytelnika do niezwykle istotnej publikacji włoskiego romanisty - G. Pugliese, Linee generali dellevoluzione del diritto penale publico durante il principato, ANRW, II.14, s. 722-789. 
że jego kłamstwa są prawdą, natomiast słabszy oskarżony mógł podczas tortur kłamać, bo tego od niego oczekiwano. Z drugiej strony Kwintylian jasno stwierdził, że tortury otwierały drogę do prawdy (s. 34). Dwojaka postawa retora w tej kwestii może dowodzić wątpliwej jakości zeznań składanych przez torturowanych.

Dalsze rozważania autorka koncentruje na statusie społecznym sprawców zgodnie z dychotomią honestiores-humiliores. Przywołuje tu szeroko A. Gelliusa i jego Noctes Atticae. Szkoda, że J. Harries nie odesłała zainteresowanego czytelnika do dalszej obfitej literatury dotyczącej samego antykwarysty i jego dzieła, bo literatura w tej kwestii jest bardzo obszerna ${ }^{13}$. Zabrakło również wskazania monografii poświęconej dychotomii honestiores-humiliores ${ }^{14}$.

Analizując koncepcję kary ${ }^{15}$ w starożytnym Rzymie, autorka przytoczyła stanowisko Gelliusa o trzech jej funkcjach. Po pierwsze, kara ma służyć poprawie i reformie sprawcy, który popełnił przestępstwo przez przypadek i przez to w przyszłości uniknąłby podobnego działania. Następnie antykwarysta wyjaśnił, że ukaranie sprawcy było niezbędne, aby ofiara nie utraciła swojej godności i nie zmniejszyła się jej estyma. Po trzecie, kara miała spełniać funkcję odstraszającą (s. 37). Choć we wstępie swojej pracy J. Harries wspominała o powoływaniu się także na zdanie Kwintyliana, to w tym przypadku pominęła jego myśl, „że wszelką karę stosuje się nie tylko dla ukarania przestępstwa, lecz także dla przykładu" ${ }^{16}$. Poza tym autorka nie przytoczyła jakże trafnego zdania Paulusa, stwierdzającego, że kara jest ustanawiana w celu poprawy człowieka ${ }^{17}$.

Ostatnim aspektem poruszanym w tym rozdziale jest kwestia błędów sędziowskich przy wydawaniu orzeczeń, które wynikały z ich niekompetencji albo nadużywania władzy dyskrecjonalnej przy wymierzaniu i tak surowych kar. Problematykę tę ilustruje bogato przykładami ze źródeł prawniczych i nieprawniczych. Prowadzone na tym obszarze badania autorka kończy krótką konkluzją podsumowującą rozważania niniejszego rozdziału.

Rozdział 4 (The theft in the night, s. 43-58) rozpoczyna właściwą część pracy poświęconą poszczególnym przestępstwom. Autorka odnotowuje, że w okresie wczesnego cesarstwa kradzież (furtum), rozbój (rapina), zniewaga (iniuria) nie były penalizowane

${ }^{13} \mathrm{Z}$ anglojęzycznej literatury tytułem przykładu można wskazać: B. Baldwin, Studies in Aulus Gellius, Lawrence 1975. W polskiej literaturze romanistycznej odrębne studium poświęcone aspektom prawa prywatnego u Gelliusa poświęcił J. Zabłocki - zob. Rozważania o procesie rzymskim w 'Noctes Atticae' Aulusa Gelliusa, Warszawa 1999; tam obszerna literatura przedmiotu.

${ }^{14}$ R. Rilinger, Humiliores-honestiores. Zu einer sozialen Dichotomie im Strafrecht der römischen Kaiserzeit, München 1988; zob. także: M. Balzzarini, Nuove prospettivie sulla dicotomia honestioreshumiliores, [w:] A. Budrese (red.), Idee vecchie e nuove sul diritto criminale romano, Padova 1988, s. 159 i nast.

15 Starożytni Rzymianie nie wykształcili teorii kary na gruncie prawa karnego - zob. W. Litewski, Podstawowe wartości prawa rzymskiego, Kraków 2001, s. 171.

${ }^{16}$ Omnis poena non tam ad delictum pertinet, quam ad exemplum - cyt. za: W. Wołodkiewicz, Czy prawo rzymskie przestało istnieć?, Kraków 2004, s. 64.

${ }^{17}$ D. 48,9,20 (Paulus 18 ad Plaut): [...] quod poena constituitur in emendationem hominum [...]. 
przez prawo karne, ale prawo prywatne, a więc były to zdarzenia rodzące obligatio ex delicto. Stąd też poszkodowana strona korzystała $\mathrm{z}$ instytucji przewidzianych w ius civile nie tylko $\mathrm{z}$ tego względu, ale przede wszystkim $\mathrm{z}$ uwagi na ryzykowną (o ile w ogóle dopuszczalną w danym przypadku) ścieżkę ius publicum (s. 44). J. Harries trafnie zauważa, że skargi ex delicto zawierały w sobie element karny, poszkodowany wnosił bowiem nie tylko o restytucję własności (np. przy furtum), ale także otrzymywał zadośćuczynienie (odszkodowanie) za popełniony delikt (np. podwójną (duplum), potrójną (tripluim) albo poczwórną (quadruplum) wartość szkody, w zależności od rodzaju kradzieży). Idąc tym tokiem rozważań, autorka w dalszej części rozdziału omawia regulację lex Aquilia oraz przedstawia ewolucję deliktu iniuria (s. 46-50). Dopiero po prezentacji tych kwestii J. Harries przechodzi do omówienia właściwego zagadnienia, tj. kradzieży (furtum). Wydaje się zatem, że nazwa tego rozdziału nie została wybrana dość trafnie, bowiem połowa rozważań, niezwykle cennych, stanowi jednak zbyt obszerne wprowadzenie do problematyki sygnalizowanej w tytule rozdziału. Warto odnotować szerokie wykorzystanie Noctes Atticae Gelliusa, które posłużyły autorce do konfrontacji informacji o furtum z tymi, które przekazał Gaius w swoich Institutiones. Podsumowując ten wycinek badań J. Harris zauważa, że rozważania Gelliusa i Gaiusa nie różnią się w żadnym stopniu, obaj bowiem poruszają te same kwestie sporne (s. 50-54). Autorka formułuje ciekawy wniosek stwierdzając, że Gellius był tak samo dobrym jurystą jak Gaius, a jedyne co ich różnicuje, to używanie przez tego drugiego wyrażeń stosowanych w kulturze prawniczej (s. 54). Trafnie spostrzega, że przepisy ustawy XII Tablic były w wielu kwestiach już anachroniczne (choć formalnie dalej obowiązywały), ale mimo to złodziej złapany na kradzieży w nocy mógł być w dalszym ciągu bezkarnie zabity przez poszkodowanego.

Po przedstawieniu informacji o furtum u Gelliusa i Gaiusa, J. Harries omawia kradzież jako crimen. Problematykę tę przedstawia cytując wyimaginowany dialog z Noctes Atticae, który prowadzą jurysta Sextus Caecilius (Africanus) (obrońca porządku prawnego Rzymu, a ustawy XII Tablic w szczególności) oraz filozof Favorinus z Arles (krytyk prawa rzymskiego za jego surowość albo pobłażliwość, czy wreszcie nonsensowność niepozwalającą literalnie interpretować przepisów - s. 55-57). Ten interesujący dyskurs ukazuje czytelnikowi, jak zagadnienia prawa karnego postrzegał jurysta, a jak filozof. Rozważania o furtum autorka kończy konkluzją wskazującą, że w okresie cesarstwa kary zostały zaostrzone, ale nie ze względu na zaangażowanie samych imperatorów, lecz również żądania stron nie tylko zadośćuczynienia, ale przede wszystkim odwetu.

Kolejne dwa rozdziały J. Harries określa zbliżonym tytułem, sprawiając tym samym wrażenie ich nierozerwalności - Controlling elites I: ambitus and repetundae (rozdz. 5, s. 59-72), Controlling elites II: maiestas (rozdz. 6, s. 73-85). W pierwszym przypadku tytuł może być mylący, gdy uwzględni się kwestie, które autorka pominęła. Omawiając przestępstwa wyborcze (ambitus), skoncentrowała się tylko na leges z II w. p.n.e. (s.60) - tj. lex Cornelia Baebia de ambitu z 181 r. p.n.e. oraz lex Cornelia Fulvia z 159 r. p.n.e. ${ }^{18}$.Zupełnie

${ }^{18}$ Podstawowe informacje o tych leges podaje G. Rotondi, Leges publicae populi romani, Milano 1912 (Nachdruck Hildesheim 1966), s. 277, 288; zob. także: M. Elster, Die gesetze der mittleren römischen Republik. Text und Kommentar, Darmstadt 2009, s. 229-340, 400-401. 
nie odniosła się do leges pochodzących z V i IV w. p.n.e. ${ }^{19}$, a przez to nakreśliła wyjątkowo wąsko problematykę ambitus we wczesnej republice rzymskiej. Należy podkreślić, że lex Poetelia de ambitu z 358 r. p.n.e., o której autorka nie wspomniała, nie dążyła do kontroli żadnych elit, a jedynie miała zahamować ambicje homines novi, którzy przez swoje zabiegi podczas elekcji (poruszanie się po targach (nundinae) oraz miejscach zebrań publicznych (conciliabulum ${ }^{20} \mathrm{w}$ celu gromadzenia głosów) aspirowali dopiero do włączenia ich do warstwy sprawującej władzę $e^{21}$. Nieporuszenie tej problematyki przez J. Harries spłyca pojmowanie fenomenu ambitus w prawie rzymskim.

Autorka trafnie zauważa, że ambitus w swoim pierwotnym sensie stopniowo traci znaczenie (dlatego, że wyboru urzędników dokonywał już cesarz, a nie comita), a w związku z tym został on przedefiniowany i rozszerzono jego zakres. Dzięki temu odpowiedzialni za to przestępstwo mogli być senatorowie oraz magistratura municypalna. Następnie J. Harries dowodzi, posługując się przede wszystkim źródłami prawnymi, że ambitus przyjął jeszcze inny wymiar w późnym cesarstwie rzymskim, jako np. przestępstwo korupcji (s. 60).

Przechodząc do omawiania res repetundae - drugiego z zagadnień rozdz. 5 - autorka czyni ciekawe zastrzeżenie dotyczące terminologii, gdy uwzględni się funkcję quaestiones. Słusznie zauważa, że podstawowym celem procesu de repetundis nie było samo ukaranie sprawcy, a jedynie otrzymanie zadośćuczynienia za szkodę przez niego wyrządzoną przez wymuszenie. Stąd też tak ujęta procedura de repetundis zbliża bardziej do procesu prywatnego niż karnego. Wniosek ten pozwala autorce na ostrożne formułowanie stanowiska, w myśl którego celniejszym określeniem tego zachowania byłoby concussio ${ }^{22}$, znane jurysprudencji klasycznej. Jednakże dalej wskazuje, że w okresie cesarstwa termin repetundae był rozumiany jako wymuszanie, a samo concussio było interpretowane jako przestępstwo popełnianie przez niższą administrację urzędniczą (s. 61).

Nie dziwi zatem wskazanie przez J. Harries, co jest powszechnie aprobowane $\mathrm{w}$ literaturze, na funkcjonowanie $\mathrm{w}$ ramach lex Calpurnia de repetundis ze 149 r. p.n.e. procedury prywatnoprawnej - legis actio sacramento, a także podkreślenie znaczenia fikcji obywatelstwa rzymskiego (fictio civitatis) w przypadku wnoszenia skargi przez peregryna (s. 61). Jako prawdopodobny cel wydania lex Calpurnia de repetundis podaje skargi obywateli rzymskich dotyczące wymuszeń na namiestników prowincji, włącznie z rezydującymi w Rzymie urzędnikami. Ostrożnie odnosi się do kwestii przypisywania

19 Zob. w tej kwestii przede wszystkim: L. Fascione, Alle orgini della legislazione de ambitu, [w:] F. Serrao (red.), Legge e società nella repubblica romana, t. I, Napoli 1981, s. 255-279; idem, Crimen e quaestio ambitus nell'eta repubblicana, Milano 1984, s. 20-27. Ponadto autorka nie odesłała czytelnika do wydanej stosunkowo niedawno pracy poświęconej ambitus: P. Nadig, Ardet ambitus. Untersuchungen zum Phänomenon der Wahlbestechung in der römischen Republik, Frankfurt am Main 1997 (passim).

${ }^{20}$ Liv. VII, 15, 12-13.

${ }^{21}$ Zob. ostatnio w kwestii M. Elster, op. cit., , s. 13.

${ }^{22}$ Termin ten jest interpretowany jako „wymuszenie zysku dla siebie pod pozorem przysługujacej komuś władzy, szantaż”-zob. J. Sondel, Słownik łacińsko-polski dla prawników i historyków, Kraków 2005, s.v. concussio, s. 193. 
autorstwa lex Acilia repetundarum (123-122 r. p.n.e.) Grakchusowi23. W dalszej części swoją uwagę koncentruje na ukazaniu reform procedury de repetundis (przede wszystkim omawia nominis delatio i rolę praetor peregrinus) oraz wskazuje, że repetundae staje się crimen i tym samym jest zaliczane do ordo iudiciorum publicorum. Autorka skupia się także na ocenie praktycznego aspektu obowiązywania leges de repetundis. Zauważa, że w republice odbyło się tylko kilka procesów de repetundis, przede wszystkim z uwagi na solidarność między sprawcą a orzekającym sądem, co przechylało szalę na niekorzyść sprawiedliwości. Natomiast w okresie cesarstwa brak wielu skazanych w procesach de repetundis wynikał z przejęcia kompetencji quaestio de repetundis przez senat, który sądził swoich członków (s. 66). To z pewnością wpływało na treść wydawanych wyroków. Spostrzeżenia te autorka opiera na analizie źródeł nieprawniczych. Ponadto jej badania pokazują, że w późnym cesarstwie podstawową karą za crimen repetundarum była grzywna (multa), której wysokość była zależna od czynników geograficznych (grzywna wyższa na wschodzie cesarstwa, który uchodził za bogatszy, niż na zachodzie) (s. 69).

Konkludując rozważania, J. Harries stwierdza, że pierwsze leges de repetundis nie definiowały repetundae, uczyniły to dopiero późniejsze ustawy, a w okresie cesarstwa - także komentarze jurystów. Poza tym początkowo procedura de repetundis zbliżona była do rozwiązań stosowanych w prawie prywatnym przy deliktach, gdyż poszkodowanemu nie chodziło o zadośćuczynienie czy odwet na sprawcy, a odzyskanie zabranych rzeczy.

Wyniki badań dotyczących maiestas w prawie rzymskim autorka przedstawia w rozdz. 6. Bardzo szczegółowo prezentuje początki ustawodawstwa poświęconego tej problematyce, analizując przede wszystkim źródła nieprawnicze. Zauważa, że lex Apuleia de maiestate minuta ${ }^{24}$ nie definiowała maiestas, a tym bardziej nie zastępowała powszechnie spotykanej w republice rzymskiej perduellio. Autorka stwierdza, że brak ustawowego określenia znamion maiestas mogło być wynikiem pozostawienia samemu populus do rozstrzygania, jaki czyn należało traktować w tej kategorii (s. 74). Dopiero Sulla doprowadził do eliminacji dualizmu perduellio-maiestas i klarownego rozumienia maiestas zarówno z punktu widzenia spraw politycznych, jak i wojskowych. Zauważa jednak, że nie tylko ustawa Sulli, ale także Cezara (lex Iulia de maiestate z 46 r. p.n.e. ${ }^{25}$ ) odniosły połowiczny sukces. Wynikało to z tego, że obaj legislatorzy zabronili namiestnikom opuszczania administrowanych prowincji, choć sami postępowali zupełnie odwrotnie (s. 76). Dlatego przyjęła, że lex Iulia maiestatis z 8 r. n.e. ${ }^{26}$ Augusta była podstawowym aktem prawnym regulującym tę kwestię w okresie cesarstwa i była przedmiotem zainteresowania jurysprudencji, co autorka potwierdza, cytując fragment z Digesta Iustiniani pochodzący od Ulpiana - D. 48,4,1 (s. 77).

\footnotetext{
${ }^{23}$ Zob. argumenty dotyczące datacji i treści tej lex wskazane przez G. Rotondiego, op. cit., s. 313.

${ }^{24}$ Kwestię uchwalenia tej ustawy oraz podstawowe informacje przedstawia G. Rotondi, op. cit.,

${ }^{25}$ Zob. ibidem, s. 422.

${ }^{26}$ Ibidem, s. 453.
} s. 329. 
J. Harries słusznie podkreśla, że w okresie cesarstwa najbardziej znamienna jest ewolucja maiestas popełnianego dotąd wobec populus, podczas gdy w okresie cesarstwa punkt ciężkości tego crimen został przesunięty w kierunku cesarza. Jej badania dowodzą, że już w późnym okresie panowania Augusta rola quaestio de maiestatis stopniowo upadała, a jego następca - Tyberiusz - większość spraw o crimen maiestatis przekazał do rozstrzygania senatowi (s. 78-79) ${ }^{27}$. Autorka przedstawiła także ewolucję kary za to przestępstwo - dawne interdictum aquae et ignis zastąpiono następującymi karami: rzucenie na pożarcie dzikim zwierzętom (damnatio ad bestias) lub spalenie żywcem (vivicomburnium albo vivi exuri ${ }^{28}$ ) dla humiliores, a dla honestiores przewidziano karę śmierci (capite puniri $)^{29}$ (s. 82).

Rozważania tego rozdziału autorka kończy wskazaniem dwóch aspektów tego przestępstwa - pierwszym jest perduellio w sensie ścisłym (pomoc wrogom, próba zabójstwa polityków etc.), a drugim bliżej niezdefiniowana obraza populus. Interesującym spostrzeżeniem jest stwierdzenie, że nie tylko Rzymianie nie wykształcili jednolitego rozumienia crimen maiestatis, bowiem w czasach nowożytnych (podany przykład Ludwika XVI) i we współczesnym świecie (w szczególności USA w II połowie XX w.) brak też kompleksowej definicji w tym zakresie (s. 84).

Kolejną część swoich badań autorka przedstawia w rozdz. 7 (Sex and the City, s. 86-105), prezentując swoje stanowisko odnoszące się do szeroko pojętych przestępstw na tle seksualnym i obyczajowym (gwałt - stuprum per vim, aborcja - abortio, kazirodztwo - incestum etc.). Pierwszą kwestią, jaką porusza J. Harries, jest aborcja. Pisze, że spędzanie płodu było crimen karanym exilium w III w. n.e. ( zaostrzenie kar z uwzględnieniem podziału na honestiores-humiliores przedstawia odnotowany przez autorkę fragment D. 48,19,38,5), a sama aborcja była czynem wymierzonym w ojca dziecka. Wynika to stąd, że spędzenie płodu uniemożliwiało nabycie patria potestas nad dzieckiem. J. Harries podkreśla, że juryści rzymscy (przeciwnie do filozofii chrześcijańskiej) nie poświęcali miejsca w swoich rozważaniach zagadnieniu „prawa do życia" płodu ('right to life' of the foetus). Następnie autorka skreśliła kilka słów o gwałcie (stuprum per vim), dowodząc, że jest on zaliczany do crimen vis. Zauważa jednak, że istniała także możliwość skorzystania z instytucji przewidzianych przez ius civile, a w szczególności z metus, gdy używano groźby albo w inny sposób nalegano na odbycie stosunku płciowego. J. Harries stawia ciekawą tezę, że prawo rzymskie nie obwiniało kobiety za gwałt, pod warunkiem, że była z wyższych warstw społecznych. Skoro kobieta nie wyrażała zgody na odbycie stosunku płciowego, to tym samym nie ucierpiała jej reputacja i gdy nie była zamężna, to szanse na zamążpójście nie spadały (D. 48,5,14(13),7). Z drugiej strony przedstawia pewne znieczulenie Rzymian na trau-

${ }^{27}$ Por. W. Litewski, Rzymski proces karny, Kraków 2003, s. 53.

${ }^{28}$ Taką terminologią posłużył się Paulus w swoich Sententiae (PS. 5,29,1), lecz treści tego fragmentu źródłowego J. Harries nie przytacza, koncentrując się tylko na jego analizie.

${ }^{29}$ Choć autorka tego nie wyjaśniła, to trzeba wskazać, że w tym przypadku kara śmierci była wykonywana przez ścięcie mieczem (który zastąpił powszechnie stosowany w republice topór) poprzedzone chłostą. 
mę ofiary związaną z gwałtem. Wniosek taki wypływa $\mathrm{z}$ analizy komedii rzymskich, w których fabule gwałt, nawet jeśli początkowo był traumatycznym przeżyciem, w rezultacie był postrzegany pozytywnie, skoro sprawca i ofiara zawierali małżeństwo albo okazało się, że byli już małżeństwem (s. 88).

Warto odnotować kilka uwag autorki na temat incestum. J. Harries przedstawia dwa aspekty tego czynu - jeden jest ściśle skorelowany z westalkami, a drugi odzwierciedla typowe relacje kazirodcze między krewnymi bliskiego stopnia, którym z tego powodu prawo rzymskie nie przyznawało conubium. Analizuje sposób rekrutacji westalek, przedstawia sądownictwo pontifex maximus nad kapłankami Westy. Wypada zaakcentować niezwykle trafne spostrzeżenie J. Harries, stwierdzające, że incestum było kompleksowym przestępstwem przeciwko porządkowi społecznemu z uwagi na spajanie klamrą dwóch elementów - czynnika religijnego i społecznego. Jedyny niedosyt, jaki niosą rozważania o incestum, to brak szerszego odesłania zainteresowanego czytelnika do literatury przedmiotu ${ }^{30}$.

Autorka poczyniła też kilka ciekawych uwag w przedmiocie cudzołóstwa (adulterium $)^{31}$. Trafnie odnotowuje dwie kwestie związane z tym przestępstwem. Po pierwsze zauważa, że dziecko zrodzone w wyniku popełnienia adulterium mogło wejść do rodziny pater familas, który nie był jego biologicznym ojcem, a efekt takiej „inkorporacji” miał swój doniosły skutek w prawie spadkowym. Po drugie, adulterium powodowało naruszenie honoru rodziny rzymskiej, co nie było bez znaczenia w starożytnym Rzymie. Kontynuując rozważania o tym przestępstwie, J. Harries przedstawia lex Iulia de adulteriis cöercendis z 18 r. p.n.e. ${ }^{32}$, a w szczególności jej innowację, polegającą na tym, że August dążył do eliminacji z życia społecznego m.in. adulterium, a gdy nawet ono wystąpiło, to zawsze było karane. Mąż, który nie odprawił żony przyłapanej na cudzołóstwie, mógł byś sam oskarżony o stręczycielstwo (lenocinium) ${ }^{33}$ (s. 98). W tym wypadku nie chodziło o to, czy mąż czerpał korzyść materialną. Sam fakt pozostawania z cudzołożnicą w związku małżeńskim podlegał penalizacji.

Odrębny podrozdział autorka poświęciła stanowisku Kwintyliana co do adulterium. Zajęła się także wykazaniem sankcji karnych, jakie groziły za to przestępstwo. W wyniku poczynionych badań ustaliła, że właściwa kara grożąca sprawcy za adulterium jest

${ }^{30}$ Zob. np. M. Beard, The sexual Status of Virgines Vestales, JRS 70, 1980, s. 12-27; obszerny artykuł A. Guarino, Studi sull'incestum, ZSS 63, 1943, s. 175-267. W ostatnim czasie ukazała się w jęz. polskim monografia poświęcona incestum - J. Misztal-Konecka, Incestum w prawie rzymskim, Lublin 2007 (passim); tam także szczegółowa bibliografia.

${ }^{31}$ Autorka także w tej kwestii nie wskazała czytelnikowi szczegółowej i obszernej literatury przedmiotu. Tytułem przykładu można podać M. de Dominicis, Sulle origini romano-cristiane del diritto del marito ad accusare constante matrimonio la moglie adultera, SDHI 16, 1950, s. 221-253; M. Andréev, Divorce et adultè dans le droit romain classique, RHD 35, 1957, s. 1-32; J. A. C. Thomas, Accusatio adulterii, IURA 12, 1961, s. 65-80; G. Rizzelli, Alcuni aspetti dell'accusa privilegiata im materia di adulterio, BIDR 28, 1986, s. 411-441; idem, Stuprum e adulterium nella cultura e la lex Iulia de adulteriis, BIDR 29, 1987, s. $355-388$.

${ }^{32}$ G. Rotondi, op. cit., s. 445.

${ }^{33}$ Zob. w tej kwestii monografię A. Sokali, Lenocinium w prawie rzymskim, Toruń 1992 (passim). 
niepewna, ale prawdopodobnie nie była to kara śmierci (s. 103). Opowiada się za następującymi karami: deportacją na wyspę, konfiskatą części majątku. Słusznie podnosi, że rzymska elita była niechętna do wyjaśniania przed quaestio spraw o adulterium, gdyż rzutowało to na pozycję społeczną, w szczególności na honor rodziny.

Trzeba podkreślić, że jest to drugi rozdział, który autorka pozostawia bez konkluzji, a kończy go w dość nietypowy sposób, omawia bowiem kwestię adulterium w późnym antyku. Bardziej zasadne wydaje się umieszczenie tych informacji w ramach podrozdziału poświęconego w całości temu problemowi, a nie rozbijanie go na dwie odrębne jednostki redakcyjne.

Przedostatni rozdział recenzowanej pracy (Remedies for violence, s. 106-117) dotyczy obu aspektów przemocy ( $v i s$ ) - zarówno na gruncie prawa prywatnego, kiedy to poszkodowany mógł korzystać z instytucji metus, regulacji lex Aquilia oraz iniuria, jak i prawa karnego - lex Cornelia de sicariis et veneficis ${ }^{34}$. Autorka zauważa, że vis była poważnym przestępstwem w życiu Rzymian, skoro w ciągu kilkudziesięciu ostatnich lat republiki uchwalono kilka ustaw poświęconych tej problematyce (s. 107) ${ }^{35}$. Słusznie podnosi, że nie można było postawić w stan oskarżenia tłumu wywołującego tumulty lub zamieszki. Przegląd źródeł (s. 108-109) dotyczący tych zachowań wskazuje, że w istocie był to poważny problem w imperium rzymskim. W późnym antyku wobec sprawców zamieszek i tumultów stosowano damnatio ad bestias albo deportatio. W okresie schyłku cesarstwa rzymskiego ciężar tego rodzaju przestępstw przesunął się w kierunku ścigania ataków chrześcijan na pogan, chrześcijan na innych mieszkańców imperium (wnioski te wynikają z analizy odpowiednich fragmentów Codex Theodosianus) (s. 109).

Pisząc o samej lex Iulia de vi, stwierdza, że trudno jest uchwycić istotę crimen vis i oddzielić tę definicję od późniejszych jej modyfikacji. Szeroka analiza źródeł pozwala czytelnikowi na śledzenie ewolucji vis w prawie rzymskim (s. 111). J. Harries podnosi, że juryści rzymscy przyznawali poszkodowanemu w ramach crimen vis dwie drogi dochodzenia swoich roszczeń - albo na drodze prywatnej (korzystanie z interdictum unde vi w celu odzyskania rzeczy), albo skorzystanie ze środków prawnych przewidzianych przez lex Iulia.

Nie po raz pierwszy na kartach recenzowanej monografii przeplatają się wątki prywatnoprawne z instytucjami prawnokarnymi. Szczególnie widoczne jest to przy dalszej analizie crimen vis, gdzie J. Harries szeroko omawia ochronę przyznawaną w postaci interdyktów unde vi, de vi armata przez praetor urbanus oraz praetor peregrinus (s. 112-115). Ponadto autorka zauważa istotny problem, jakim są szkody wyrządzone przez uzbrojoną grupę i które nie muszą zawsze sprowadzać się do popełnienia kradzieży. Pojawia się wtedy pytanie - jak należy ukarać sprawców? Rozwiązaniem tego problemu jest konieczność zdefiniowania takiej liczby uczestników, którzy gromadząc się, mogą

${ }^{34} \mathrm{~W}$ polskiej romanistyce badania nad tą lex prowadził K. Amielańczyk - zob. np. Lex Cornelia de sicariis et veneficis, Annales UMCS, Sec. G. Ius 43, 1996, s. 273-295; Judicial crimes according to the 'Lex Cornelia de sicariis et veneficis' (81 B.C.), Pomerium 2, 1996, s. 59-70; The Position of Incendium in the Legislature of Cornelius Sulla 'Lex Cornelia de sicariis et veneficis', OIR 5, 1999, s. 5-19.

${ }^{35}$ Por. G. Rotondi, op. cit., s. 106, 377, 410, 422. 
wywoływać zamieszki - tj. 10-15 osób. Wtedy zadanie poszkodowanego było ułatwione - nie musiał wykazywać, że oskarżony zwołał tłum, ale że uczynił to w celu wyrządzenia szkody (s. 112).

W konkluzji autorka stwierdza, że przemoc była istotnym zjawiskiem w życiu Rzymian. Ofiary crimen vis na prowincji oczekiwały zadośćuczynienia, ale rezultat, jaki chciały osiągnąć, był nieprzewidywalny. Wynikało to z tego, że vis była przestępstwem silniejszych wobec słabszych, których droga do sprawiedliwości była ograniczona przez patronat oraz permanentne dążenie elit do „troszczenia się” o swoje sprawy. Stąd też, zauważa J. Harries, podejmowane działania legislacyjne nigdy nie mogły przynieść pożądanego rezultatu.

Rozdział IX (Representation of murderer, s. 118-132), będący ostatnim w recenzowanej monografii, jest w przeważającej części poświęcony procesowi Apulejusza. Jednakże zanim J. Harries w szczegółowy sposób przybliżyła tę kwestię, ponownie zajęła się problematyką lex Cornelia de sicariis et veneficis. Jest to swoistego rodzaju powtórzenie pewnych treści omawianych w rozdziale poprzedzającym. J. Harries po raz kolejny pisze tutaj o odpowiedzialności karnej podpalacza oraz uzbrojonego sprawcy, mającego zamiar popełnić zabójstwo, wskazując, że sam zamiar podlegał penalizacji (por. s. 107 oraz s. 119). Trudno jest wyjaśnić to powtórzenie i wydaje się, że pominięcie wyżej wymienionej kwestii w tym podrozdziale w znaczący sposób nie wpłynęłoby na przyjęty tok rozumowania autorki. Fragment tego rozdziału J. Harries poświęca na analizę SC Silanianum ${ }^{36}$ (s. 120).

Przechodząc do przedstawienia procesu Apulejusza (koniec II w. n.e.), autorka wskazuje, ze był on sądzony na podstawie lex Cornelia de sicariis et veneficis. Trafnie spostrzegła, że ustawa ta nic nie mówiła o penalizacji magii, a dopiero Pauli Sententiae (III w. n.e.) wprowadziły odpowiedzialność karną za jej uprawianie. Dlaczego więc Apulejusz odpowiadał na podstawie ustawy Sulli? Próbując wyjaśnić tę kwestię, J. Harries podniosła, że zarówno trucizna, jak i czary były przygotowywane w tajemnicy, co mogłoby mieć związek z odpowiedzialnością na podstawie tej lex. Jednakże taka argumentacja nie przekonuje samej autorki, która bardziej skłania się ku tezie stwierdzającej, że proces Apulejusza toczył się nie w wyniku tego, że ktokolwiek został zabity w wyniku praktyk magicznych, ale magii per se uprawianej przez niego (s. 124). Sam Apulejusz natomiast łączył swoją odpowiedzialność z faktem małżeństwa z Pudentillą i konsekwencjami finansowymi z tego wynikającymi (s. 125). Dalsze rozważana autorki skoncentrowały się na wyjaśnieniu zarzutów stawianych Apulejuszowi oraz wykazaniu jego linii obrony (s. 126). Analiza zagadnień tego rozdziału kończy się krótką konkluzją, syntetyzującą wyniki tego wycinka badań.

${ }^{36} \mathrm{~W}$ polskiej romanistyce te SC analizowała ostatnio E. Loska oraz K. Amielańczyk - zob. E. Loska, Obowiązek niewolników obrony swojego właściciela, „Zeszyty Prawnicze” [UKSW] 4.1, 2004, s. 45-56; K. Amielańczyk, Głos cesarza Hadriana w sprawie s.c. Silanianum, „Zeszyty Prawnicze” [UKSW], 6.1, 2006, s. 9-25. U obydwu autorów dalsze odesłanie do literatury. 
Warto odnotować brak podsumowania całości rozważań przeprowadzonych przez autorkę. Umieszczenie syntetycznej konkluzji z pewnością ułatwiłoby czytelnikowi obserwację wszystkich wniosków, jakie J. Harries wyciągnęła, analizując każdą z kwestii poruszanych w poszczególnych rozdziałach. Pewnym mankamentem jest także niezamieszczenie indeksu cytowanych źródeł, co jest praktycznie standardem we wszystkich monografiach romanistycznych. Wskazane wyżej braki w podstawowej literaturze przedmiotu należy uzupełnić o uwagę o skromnym wykorzystaniu innej literatury niż anglojęzyczna. W swojej właściwej bibliografii (s. 137-142), pomijam poprzedzający ją krótki esej bibliograficzny (s. 133-136), J. Harries zacytowała tylko kilkanaście prac w języku niemieckim, włoskim oraz francuskim (tych było najwięcej), co w pewien sposób wpływa na wartości poznawcze pracy. Tak wybiórcze przedstawienie literatury uniemożliwiło prowadzenie polemiki z poglądami innych romanistów niż anglojęzyczni. Choć autorka we wstępie zaznaczyła, że jej praca nie może być traktowana jako przewodnik po prawie karnym, to zastrzeżenie takie nie powinno być usprawiedliwieniem braku zacytowania rozległej, przynajmniej podstawowej obcojęzycznej literatury przedmiotu.

Pomimo wskazanych uwag nie sposób odmówić autorce nowatorskiego spojrzenia na pewne aspekty rzymskiego prawa karnego. W pierwszej kolejności dotyczy to umiejętnego wplatania w wątki prawnokarne instytucji prawa prywatnego i pokazanie czytelnikowi, że poszkodowany mógł w celu ochrony swoich praw korzystać z instytucji prawnych obu tych gałęzi (tam, gdzie było to możliwe). Na uwagę zasługuje także ciekawe spojrzenie na rzymskie prawo karne przez pryzmat myśli Gelliusa, Kwintyliana, M.T. Cicero czy Apulejusza. Wreszcie trzeba podkreślić, że J. Harries wyjątkowo oszczędnie cytuje źródła w oryginale, a bardziej koncentruje się na ich analizie. Dzięki temu zabiegowi nawet czytelnik mający skromną wiedzę z zakresu prawa rzymskiego i języka łacińskiego będzie w stanie zapoznać się z jakże fascynującym rzymskim prawem karnym. 